\title{
Changes in zooxanthellar densities and chlorophyll concentrations in corals during and after a bleaching event
}

\author{
Ross J. Jones* \\ Department of Biochemistry, James Cook University, Townsville, Queensland 4811, Australia
}

\begin{abstract}
In January 1994 a coral bleaching event occurred on the reefs of Magnetic Island (Australia) immediately after a period of anomalously high air temperatures. Average daily water temperature increased by $2^{\circ} \mathrm{C}$ over $1 \mathrm{wk}$, reaching $34^{\circ} \mathrm{C}$ (reef flat) and $32^{\circ} \mathrm{C}$ (reef slope). Bleached corals were observed soon afterwards, suggesting the bleaching event was temperature related. Bleached (light tan coloured) and unbleached (dark brown coloured) colonies of staghorn coral Acropora formosa sampled during and after the bleaching event had lower zooxanthellar densities and higher chlorophyll a (chl a) concentrations per zooxanthella than the same colonies sampled 10 mo after the bleaching event. Significant increases in zooxanthellar chl a concentrations were measured in 2 colonies which were sampled and found to be losing zooxanthellae during the event. Intrinsic differences in the densities, chlorophyll concentrations and zooxanthellar cell sizes between neighbouring colonies of the same species resulted in intraspecific variability in coral discolouration during the bleaching event.
\end{abstract}

KEY WORDS: Bleaching $\cdot$ Chlorophyll $\cdot$ Coral $\cdot$ Temperature $\cdot$ Zooxanthellae

\section{INTRODUCTION}

Coral bleaching is considered a stress reaction to abnormal environmental conditions. The extent, timing and severity of many natural bleaching events has been closely correlated with elevated seawater temperature (Glynn 1984, Cook et al. 1990, Fitt et al. 1993, Brown et al. 1995, Hoegh-Guldberg \& Salvat 1995).

Bleached corals sampled after warm-water bleaching events invariably have lower densities of symbiotic algae (zooxanthellae) than unbleached, normal coloured colonies (Yonge \& Nicholls 1931, HoeghGuldberg \& Smith 1989a, Kleppel et al. 1989, Porter et al. 1989, Fitt et al. 1993). Analyses of zooxanthellar chlorophyll concentrations have produced an equivocal picture. Kleppel et al. (1989) and Porter et al. (1989) report that bleached colonies of Agaricia lamarckii and

\footnotetext{
- Present address: School of Biological Sciences, Building A08, University of Sydney, Sydney, New South Wales 2006 Australia. E-mail: rjones@bio.usyd.edu.au
}

Montastrea annularis have lower zooxanthellar chlorophyll a (chl a) concentrations than normal coloured colonies. Hoegh-Guldberg \& Smith (1989a) and Fitt et al. (1993) report that bleached corals (Seriatopora hystrix and $M$. annularis) have higher zooxanthellar chl a concentrations. The reason for this discrepancy is unclear.

Another puzzling aspect of coral bleaching is the intraspecific variability of the response. Bleached corals are often observed beside individuals of the same species showing no signs of colour loss (Fisk \& Done 1985, Oliver 1985, see photographs in Ghiold \& Smith 1990). Manipulative experiments and field observations with Porites porites have indicated that some of the variability may be related to the differential susceptibility of clonal coral genotypes (Edmunds 1994). Differences in the thermal tolerance of the zooxanthellae and diversity of zooxanthellar genotypes between or within colonies have also been suggested as a source of the inter-and intraspecific variability of bleaching (Rowan \& Powers 1991, Fitt \& Warner 1995). 
In January 1994, a bleaching event occurred on the fringing reefs of Magnetic Island (Great Barrier Reef region, Australia) In this work, a description of the hydro-meteorological conditions over the bleaching period is given, including an analysis of air temperatures and in situ seawater temperatures. Evidence is presented from corals sampled during and after the event to suggest that bleaching can occur through loss of zooxanthellae without decreases in zooxanthellar chl a concentrations. An examination is made as to why some colonies of Pacific staghorn coral Acropora formosa bleached whilst other neighbouring colonies did not. This includes an analysis of zooxanthellar densities, chl a concentrations and zooxanthellar cell sizes.

\section{MATERIALS AND METHODS}

Magnetic Island $\left(19^{\circ} \mathrm{S}, 147^{\circ} \mathrm{W}\right)$ is a continental island situated $\sim 8 \mathrm{~km} \mathrm{~N}$ of the mainland city of Townsville (Fig. 1). Fringing reefs occur on the SE side of the island as assemblages of coral and algae overlying platforms of accumulated non-biogenic sediments. The fringing reefs are situated in turbid waters: underwater visibility ranges from approximately $<0.2$ to $10 \mathrm{~m}$.

Signs of bleaching on reefs at Magnetic Island were first observed by the Great Barrier Reef Marine Parks Authority (GBRMPA) Research and Monitoring Section on 16 January 1994. Scuba-diving instructors from a commercial diving outlet based on Magnetic Island also observed discolouration of corals in mid January

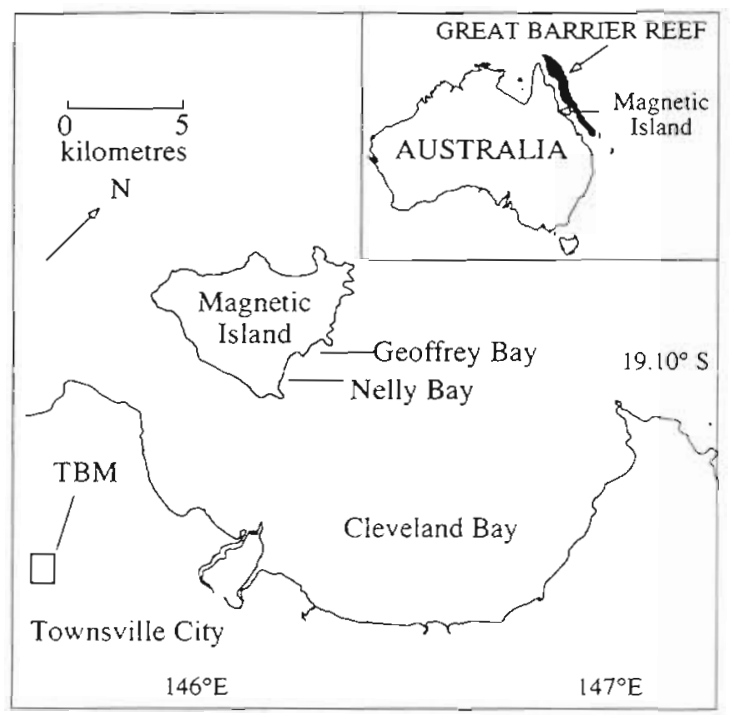

Fig. 1. Nelly Bay (coral sampling) and Geoffrey Bay (seawater temperature measured), on Magnetic Island, and the Townsville Bureau of Meteorology (TBM; air temperatures measured) on the adjacent mainland (Australia)
1994, but observed no discolouration of corals in late December 1993. It is likely the bleaching event started in the first 2 wk of January 1994.

Hydro-meteorological conditions. Air temperatures (accuracy $0.1^{\circ} \mathrm{C}$ ) recorded at the Townsville Bureau of Meteorology (TBM) were obtained for the period 20 December 1993 to 2 February 1994. The TBM weather station is located on the Australian mainland $\left(19.15^{\circ} \mathrm{S}, 145.46^{\circ} \mathrm{E}\right), \sim 10 \mathrm{~km} \mathrm{~S}$ of Magnetic Island (Fig. 1). Seawater temperatures at Geoffrey Bay between 20 December 1993 and 2 February 1994 were measured in situ by waterproof platinum RTD thermocouple sensors (accuracy $\pm 0.1^{\circ} \mathrm{C}$ ) and recorded onto data loggers. Water temperatures were measured on the reef flat ( $1 \mathrm{~m}$ depth; GBRMPA Research and Monitoring Section), and reef slope (5 $\mathrm{m}$ depth; Stobart 1994). The average, maximum and minimum daily temperatures were determined from recordings every $0.5 \mathrm{~h}$ (reef flat) and every $1 \mathrm{~h}$ (reef slope), from all available data loggers ( $\mathrm{n}=1$ or 2 loggers at each site).

Sampling of corals. On 28 January 1994, 5 'browntipped' branches (see Oliver 1984) were sampled from one bleached (light tan coloured) colony (Colony 1 ) of a staghorn coral, Acropora formosa (Dana 1846), at 5 to $6 \mathrm{~m}$ depth in Nelly Bay, Magnetic Island (Fig. 1, Table 1). Five brown-tipped branches were also taken from a neighbouring colony of $A$. formosa (Colony 3 ) at the same depth which appeared a normal dark brown colour typical of the species at Magnetic Island. Five days later (2 February 1994) and 10 mo later (1 December 1994), a further 5 brown-tipped branches were sampled from the same colonies. The zooxanthellar density and zooxanthellar chl a concentrations were determined in the branch tips. All brown-tipped branches involved in this study were selected randomly from the respective colonies.

On 14 February 1994, 2 colonies of Acropora formosa at 5 to $6 \mathrm{~m}$ depth in Nelly Bay which the zooxanthellar densities prior to the bleaching event were known (Jones 1997) were located. One of the colonies (Colony 2) had bleached to a light tan colour and the other colony (Colony $4_{i} \sim 3 \mathrm{~m}$ away) showed no signs of colour loss. At 2 to $4 \mathrm{wk}$ intervais for the remainder of the year 5 brown-tipped branches were sampled from each of the 2 colonies and the zooxanthellar density, zooxanthellar chl a concentration and zooxanthellar cell size determined.

In the second week of February 1994, 4 bleached colonies of Acropora formosa and 5 colonies which showed no signs of colour loss were tagged for later studies (see Table 1). All colonies were located at 5 to $6 \mathrm{~m}$ depth on the reef slope at Nelly Bay and separated from each other by 3 to $10 \mathrm{~m}$. In December 1994, $10 \mathrm{mo}$ after the bleaching event, 5 brown-tipped branches were excised from each of the colonies and the zoo- 
Table 1 Sampling dates of bleached and 'normal' coloured colonies of Acropora formosa (Magnetic Island, Great. Barrier Reef region, Australia)

\begin{tabular}{|lll|}
\hline Sampling date (1994) & Bleached colonies & 'Normal' coloured colonies \\
\hline 28 January & Colony 1 sampled & Colony 3 sampled \\
2 February & Colony 1 re-sampled & Colony 3 re-sampled \\
14 February & Colony 2 sampled, 4 bleached colonies & Colony 4 sampled, 5 'normal' coloured \\
& (including Colony 1) tagged for later & colonies (including Colony 3) tagged for \\
14 February to 1 December & studies (see December 1994) & later studies (see December 1994) \\
28 November to 1 December & 4 colonies which bleached sampled & Repetitive sampling of Colony 4 \\
& (see 14 February) & 5 colonies which did not bleached sampled \\
& & (see 14 February)
\end{tabular}

xanthellar density, zooxanthellar chl a concentration and zooxanthellar cell sizes determined.

Processing of corals. All coral samples were frozen for $1 \mathrm{~h}$ before being transported to the laboratory packed in ice. Within $3 \mathrm{~h}$ of collection, tissues were removed from the skeletons with a jet of $0.45 \mu \mathrm{m}$ filtered seawater using a WaterPik ${ }^{\text {MM }}$ (Johannes \& Wiebe 1970). Small subsamples of the tissue homogenate were taken for analysis of zooxanthellar densities, chl a concentration (see Jones 1997 for methods) and zooxanthellar cell size (the largest linear diameter of 50 zooxanthellae from each of the tips, measured using a calibrated occular micrometer at $1000 \times$ magnification under oil immersion). Zooxanthellae volume was calculated by assuming the cells to be spherical. The total number of zooxanthellae was normalised to the number of polyps recorded by visual census (Muscatine et al. 1991).

Data are presented as mean $\pm 95 \%$ confidence intervals (CI). Data were analysed $(\alpha=0.05)$ using Type I ANOVA (JMP 1994) and Student's t-test. Dunnett's test of significance was used to compare the nature of significant differences between bleached and unbleached colonies. Prior to all analyses, assumptions of normality (Shapiro-Wilk's test) and homogeneity of variance (Welch's test) were tested.

\section{RESULTS}

\section{Hydro-meteorological conditions}

There were 2 periods of elevated air temperatures in the Magnetic Island area in January 1994 (Fig. 2). The first period ( 4 to 11 January) included the highest maximum air temperature $\left(44.3^{\circ} \mathrm{C}, 7\right.$ January) recorded at the Townsville Bureau of Meteorology (TBM) since records began in 1942. The second period $(\sim 19$ to 23 January) included the second highest minimum (night time) air temperature $\left(29^{\circ} \mathrm{C}, 22\right.$ January) since records began in 1942. In late January average daily
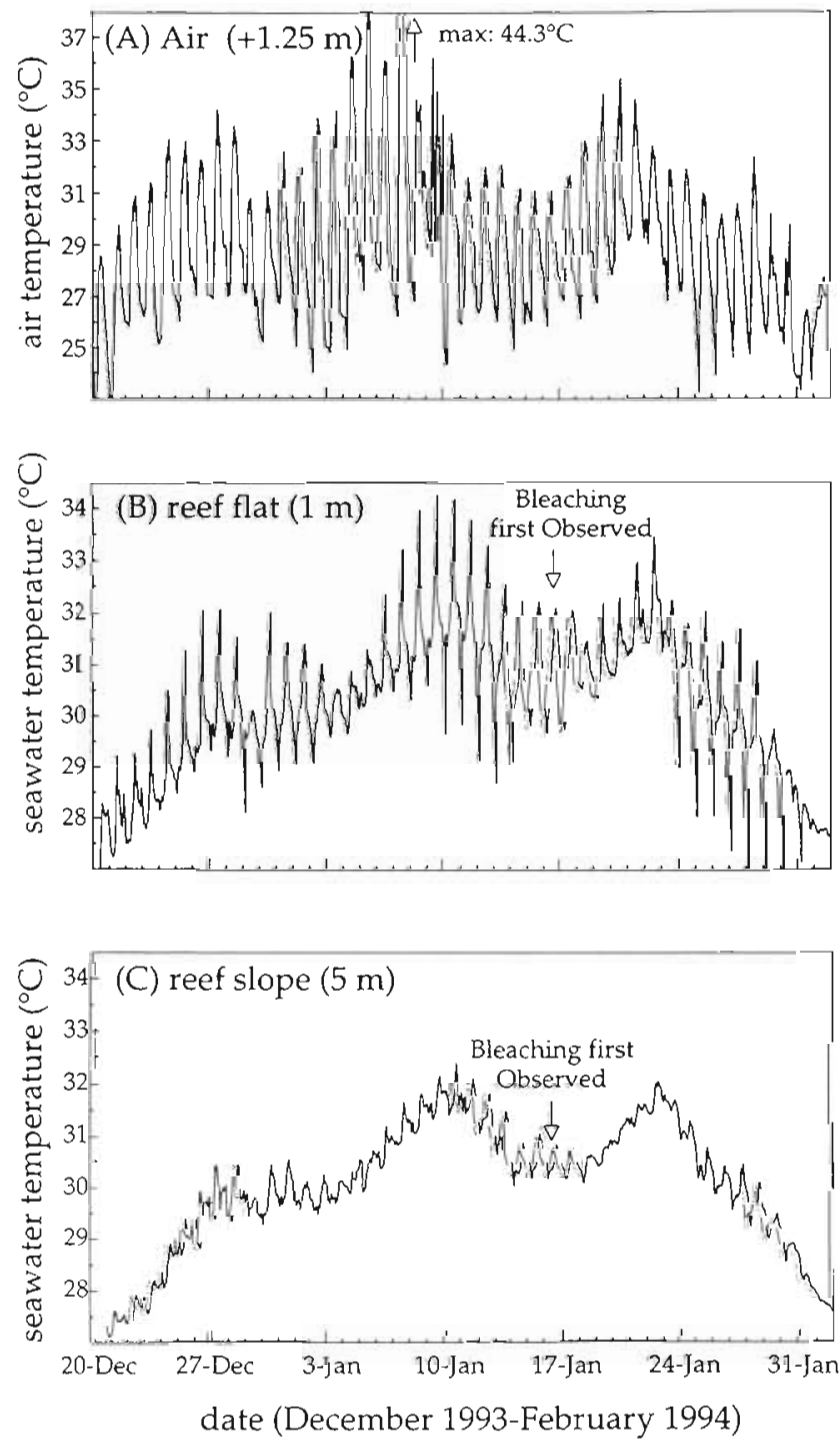

Fig. 2. (A) Air temperature (recorded every $3 \mathrm{~h}$ at the Townsville Bureau of Meteorology), (B) seawater temperature on the reef flat (recorded every $0.5 \mathrm{~h}$ at $1 \mathrm{~m}$ depth at Geoffrey Bay, Magnetic Island), and (C) seawater temperature on the reef slope (recorded every $1 \mathrm{~h}$ at $5 \mathrm{~m}$ depth at Geoffrey Bay) over the period 20 December 1993 to 2 February 1994 

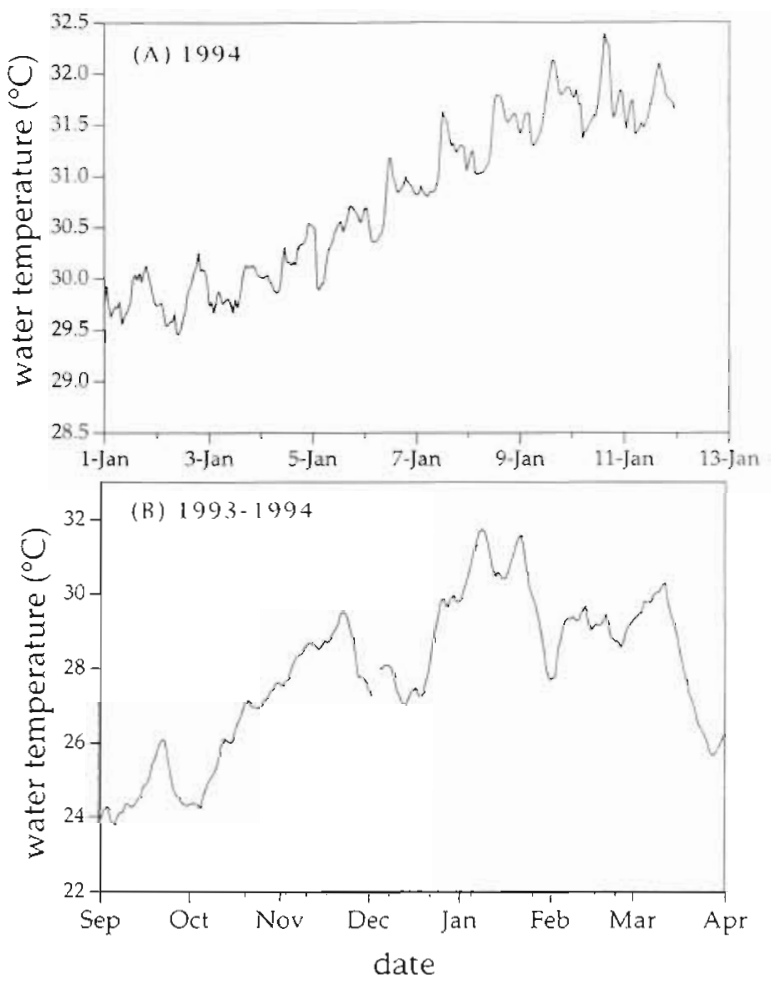

Fig. 3. Average daily seawater temperature (A) from 1 to 12 January 1994 and (B) from September 1993 to April 1994 recorded every $1 \mathrm{~h}$ on the reef slope ( $5 \mathrm{~m}$ depth) at Geoffrey Bay. Bleached corals were first observed at Magnetic Island on 16 January 1994

air temperatures fell sharply to $<25^{\circ} \mathrm{C}$ during storm activity associated with a decaying cyclone. January 1994 was the warmest month recorded at the TBM since 1942 (average temperature $=29.7^{\circ} \mathrm{C}$ ).

There were 2 periods of elevated seawater temperatures at Magnetic Island in January 1994, from 7 to 13 January and 19 to 24 January (Fig. 2). During these periods the average daily seawater temperature on the reef flat and slope exceeded $31^{\circ} \mathrm{C}$. Maximum seawater temperature recorded on the reef flat $\left(34.3^{\circ} \mathrm{C}, 9 \mathrm{Janu}\right.$ ary) and reef slope $\left(32.4^{\circ} \mathrm{C}, 10\right.$ January) occurred 2 to $3 \mathrm{~d}$ after the record in maximum air temperature. The average daily seawater temperatures on the reef slope increased from $30^{\circ} \mathrm{C}$ to $32^{\circ} \mathrm{C}$ over an $8 \mathrm{~d}$ period before bleached corals were first observed (Fig. 3). Average daily seawater temperatures fell rapidly in late January to $\sim 28^{\circ} \mathrm{C}$ in early February 1994 (Figs. $2 \& 3$ )

Over the period 6 to 11 January, the maximum daily seawater temperature occurred close to the predicted daytime low water (Fig. 4), and average daily seawater temperatures increased as the tides changed from neaps to springs (see also Fig. 2). The maximum seawater temperature, and the highest average daily seawater temperature in January 1994, occurred on 9 Jan- uary (reef flat) and 10 January (reef slope), when the spring tides were at their lowest and when low water occurred in the early afternoon. After 11 January the tides changed back towards neaps, the daytime low water occurred in the late afternoon at $-16: 00 \mathrm{~h}$, and the average daily seawater temperatures decreased (Figs. 2 \& 4).

\section{Zooxanthellar densities and chl a concentrations}

The zooxanthellar density in 2 colonies of Acropora formosa (Colony 1, bleached, and Colony 3, normal coloured) decreased by 27 and $25 \%$ respectively between 28 January and 2 February 1994 (Fig. 5; Student's $t$-test, $p<0.05$ ). Zooxanthellar chl a concentration in both colonies increased by 32 and $14 \%$ respectively (Student's $t$-test, $p<0.05$ ) over the same period. Both colonies were sampled again in December 1994 (10 mo after the bleaching event). At that time the zooxanthellar densities had increased 3 -fold (bleached colony) and 1.8-fold (normal coloured colony; Student's t-test $\mathrm{p}<0.05$ ).
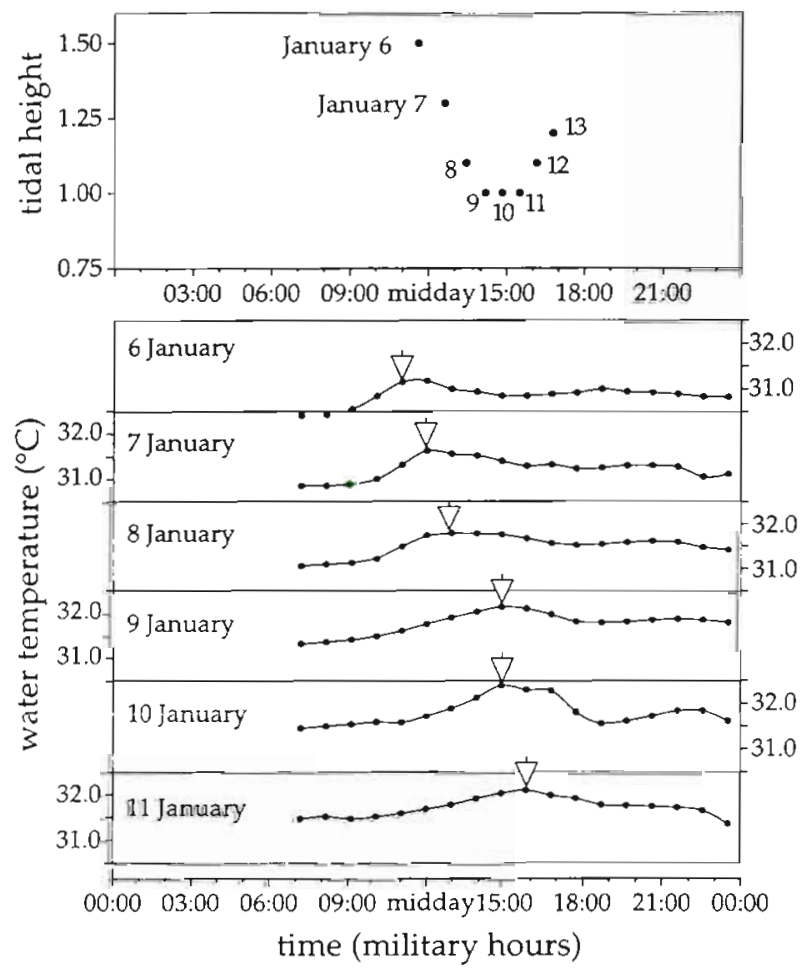

Fig. 4. Predicted times of daytime low water at Magnetic Island ( $m$ above chart datum) from 6 to 13 January 1994, and daily seawater temperature profiles on the reef slope (recorded every 1 h at $5 \mathrm{~m}$ depth) at Geoffrey Bay, Magnetic Island. $Y$-axes scales on the temperature profiles range from 30 to $32.5^{\circ} \mathrm{C}$. Arrows indicate maximum daily seawater temperature in each profile 

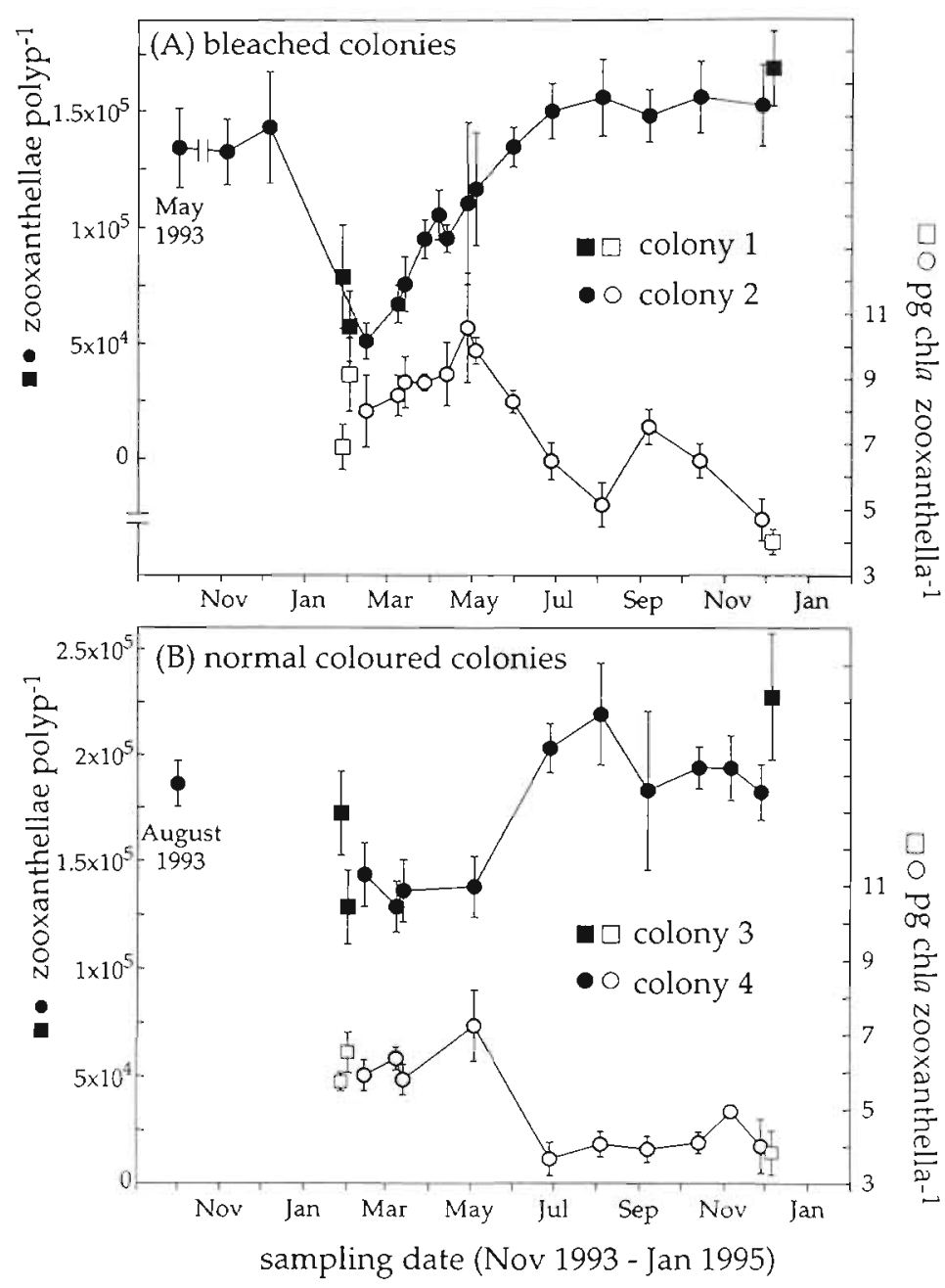

Fig. 5. Acropora formosa. Mean zooxanthellar density polyp ${ }^{-1}$ and pg chl a zooxanthella ${ }^{-1}(\square, O)$ in the terminal 40 to $50 \mathrm{~mm}$ of branch tips from (A) 2 bleached (light tan coloured) colonies and (B) 2 normal (dark brown) coloured coral colonies. Colonies 1 and 3 (bleached and unbleached respectively) were sampled during the bleaching event and again in December 1994. $\bar{x} \pm 95 \% \mathrm{CI}, \mathrm{n}=5$ branch tips per data point

$-1.8 \times 10^{5}$ zooxanthellae polyp ${ }^{-1}$ (normal coloured colony; Fig. 5).

If the zooxanthellar density and zooxanthellar chl a concentrations in the 4 colonies in December 1994 are considered to be representative of 'normal' levels, then the colonies lost 65 and $66 \%$ (bleached colonies) and 44 and $48 \%$ (normal coloured colonies) of their zooxanthellar complement during the bleaching event. Zooxanthellar chl a concentrations were significantly higher when each of the colonies were first sampled than they were in December 1994 at the end of the study (Student's $t$-test $\mathrm{p}<0.05)$.

There was a significant inverse relationship between chl a concentration and zooxanthellar density using the data collected from the colonies of Acropora formosa over the study period $(\mathrm{p}<0.05, \mathrm{r}=0.68$; Fig, 6)

The mean zooxanthellar cell volume in Colony 2 (bleached) was significantly larger than that in Colony 4 (unbleached) when first sampled (Fig. 7; ANOVA, p < 0.05). There was no change in the mean zooxanthellar volume in either colony over the course of the year.

Ten months after the bleaching event, the zooxanthellar density, zooxanthellar chl a concentration and zooxanthellar cell size were determined in 4 colonies which were known to have bleached and 5 colonies which were known to have shown no signs of colour loss. Bleached colonies had regained their colouration by May 1994, and there was no difference in colour between the 2 groups of colonies at the time of sampling (December 1994). There was no significant difference in chl a concentration per polyp between the 2 groups (ANOVA, p > 0.05; Fig. 8). However, there were significant differences in zooxan-

On 14 February 1994, 2 colonies of Acropora formosa (Colonies 2 and 4) were located in which the zooxanthellar densities had been measured prior to the bleaching event. One of the colonies had bleached to a light tan colour (Colony 2) and the other colony (Colony 4) appeared a normal dark brown colour. The zooxanthellar density in both colonies at the time of sampling was markedly lower than before the bleaching event (Fig. 5). From mid February until late April 1994, both the zooxanthellar density and zooxanthellar chl a concentration increased in both colonies. By early May 1994 the bleached colony had regained its normal colouration. From this point onwards the zooxanthellar density continued to increase to a steady-state level of $\sim 1.5 \times 10^{5}$ zooxanthellae polyp ${ }^{-1}$ (bleached colony) and thellar densities, chl a concentrations per zooxanthella and zooxanthellae cell size between the bleached and unbleached groups (Fig. 8; ANOVA, $p<0.05$ ). Colonies which bleached had fewer zooxanthellae which were larger and had more chl a per zooxanthellae than colonies which did not bleach.

\section{DISCUSSION}

\section{Hydro-meteorological conditions}

The 1994 bleaching event at Magnetic Island is a clear example of a warm-water bleaching event. Average daily seawater temperatures increased by $2^{\circ} \mathrm{C}$ in 


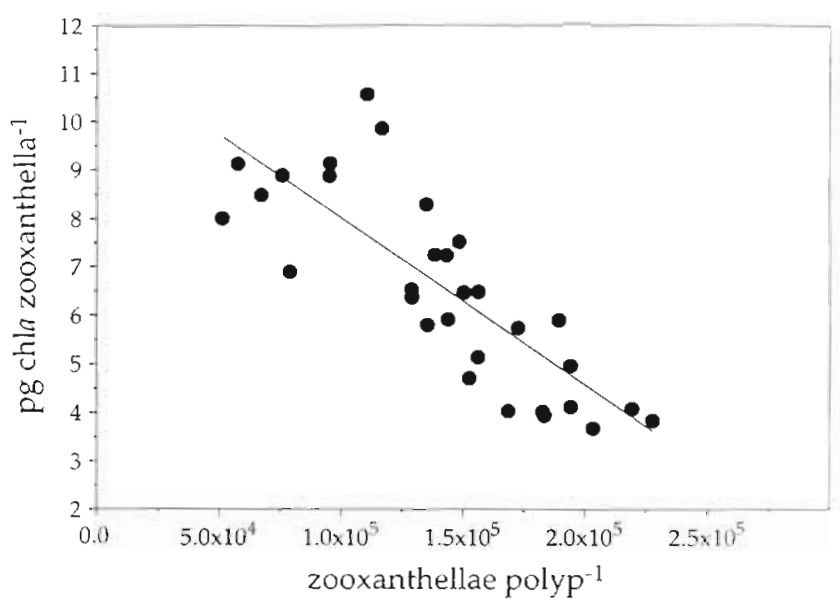

Fig. 6. Acropora formosa. Relationship between zooxanthellar chl a concentration and zooxanthellar density in colonies sampled during and after a bleaching event. Each value represents the mean of 5 branch tips from each colony

1 wk, reaching $32^{\circ} \mathrm{C}$ (reef slope) and $34^{\circ} \mathrm{C}$ (reef flat), and bleached corals were observed soon afterwards. Unlike bleaching events in the Pacific which appear related to large scale oceanographic features (HoeghGuldberg \& Salvat 1995), the 1994 bleaching event Magnetic Island was caused by a period of anomalously high air temperatures (see also Jones et al. 1997 in this volume).

An interesting feature of the event was the tidal modulation of the daily heating cycle on the reef. Over a 1 wk period before bleached corals were first observed, the maximum daily seawater temperature coincided with the daytime low water, and average daily seawater temperatures increased during the change from neap tides to spring tides (Fig. 4). Coral bleaching has been observed following sub-aerial exposure or extreme low tides (Yamazato 1981, Brown et al. 1994); however, neither were corals sub-aerially exposed, nor were daytime low tides extreme during the 1994 bleaching event at Magnetic Island. A different tidal regime could have led to a more intense or benign bleaching event. It follows that variations in tidal range and timing of daytime low water may contribute to between-reef variability in coral bleaching during periods of regionally elevated air temperatures.

\section{Zooxanthellar densities and chl a concentrations}

The results of this study suggest that, for a taxon of Acropora, loss of zooxanthellae can occur without decreases in zooxanthellar chlorophyll concentrations during a warm-water bleaching event (Fig. 5). In fact, in the 2 colonies which were losing zooxanthellae dur- ing the bleaching event, the zooxanthellar chl a concentrations actually increased (Fig. 5 ; see below).

Decreases in zooxanthellar densities in corals without decreases in zooxanthellar chl a concentrations have also been reported in corals sampled after natural bleaching events (Hoegh-Guldberg \& Smith 1989a, Fitt et al. 1993) and in corals exposed to elevated seawater temperatures during laboratory manipulations (Hoegh-Guldberg \& Smith 1989a, Glynn et al. 1992, Fitt \& Warner 1995). However, Kleppel et al. (1989) and Porter et al. (1989) report both lower zooxanthellar chl a concentrations and lower zooxanthellar densities in corals (Agaricia lamarckii and Montastrea annularis) sampled after bleaching events. In both of these cases, corals were collected between 2 and 6 mo after bleaching was first observed (see Jaap 1988, Ogden \& Wicklund 1988). Given these delays, the decrease in zooxanthellar chlorophyll concentrations reported by Kleppel et al. (1989) and Porter et al. (1989) may represent the result of (1) sustained periods of elevated seawater temperatures, (2) water temperatures higher than those measured during the present study, or (3) secondary effects of the loss of zooxanthellae.

An increase in zooxanthellar chl a concentration was measured in the 2 colonies sampled and found to be losing zooxanthellae during the bleaching event (Fig. 5). Unfortunately this result could not be verified by further sampling from additional colonies because of the abrupt end to the bleaching event in early February 1994 following decreased water temperatures and increased cloud cover during storms associated with a decaying cyclone. However, the finding is consistent with all 4 colonies involved in the study having higher zooxanthellar chl a concentrations when first

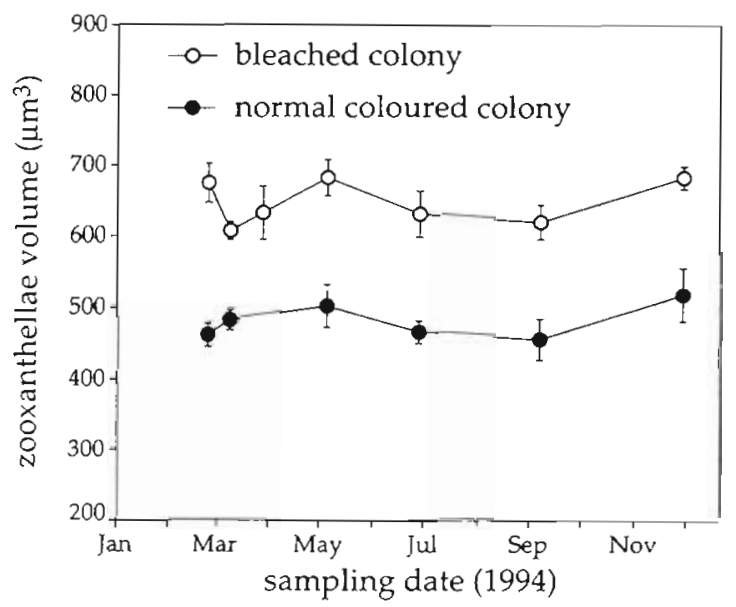

Fig. 7. Acropora formosa. Zooxanthellar cell size in a bleached colony (Colony 2, O) and neighbouring unbleached colony (Colony $4,-$ ) after a bleaching event. Each value represents the mean zooxanthellar cell size in 5 separate tips ( 50 zooxanthellae measured per tip) from each colony $(\vec{X} \pm 95 \% \mathrm{CI})$ 

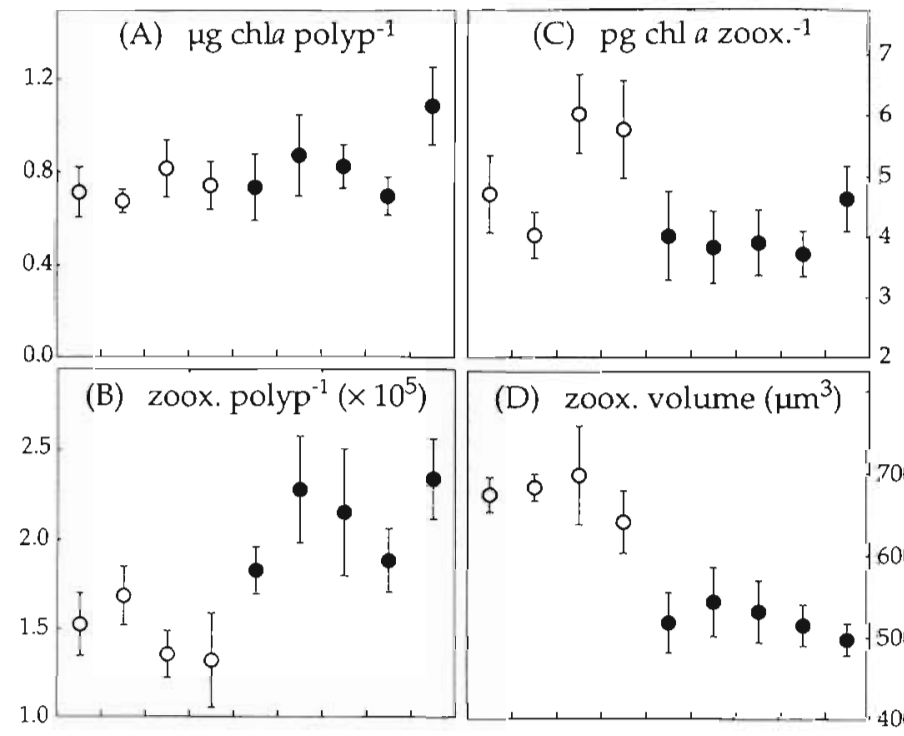

(D) zoox. volume $\left(\mu \mathrm{m}^{3}\right)$

(o) colonies which bleached, (

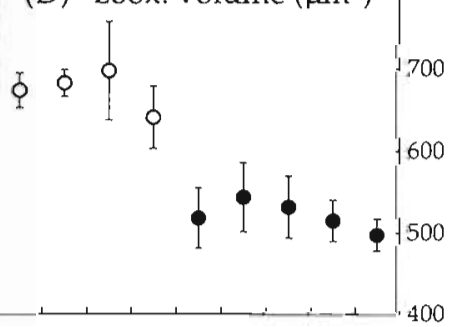

) colonies which did not bleach

Fig. 8. Acropora formosa. (A) Areal chl a concentration, (B) zooxanthellar density, (C) zooxanthellar chl a concentration, and (D) zooxanthellar size in 4 colonies which bleached $(O)$ and 5 colonies which did not bleach ( $)$ in January 1994. All colonies were sampled in early December 1994, 10 mo after the bleaching event. $\bar{x} \pm 95 \% \mathrm{Cl}$, $\mathrm{n}=5$ tips from each colony

1997, Jones \& Steven 1997). The increase in zooxanthellar chl a concentration during the bleaching event observed in this study may represent a response of the remnant zooxanthellar population to increased nutrient availability through decreased competition.

Whether the increase in zooxanthellar chl a concentration during the bleaching event is an artefact of chlorophyll breakdown products, or represents genuine changes in the zooxanthellar chl a concentration as a result of bleaching remains unclear. Marked decreases in photosynthetic performance have been measured in zooxanthellae (both in culture and in hospite) during exposure to elevated seawater temperatures (Iglesias-Prieto et al. 1992, Fitt \& Warner 1995). These changes have occurred without decreases in zooxanthellar chl a concentrations. However, chlorophyll can act as a photosensitising agent in the presence of molecular oxygen and sunlight to produce active oxygen species (Asada \& Takahashi 1987, Lesser \& Shick 1989). Increased zooxanthellar chlorophyll concentrations may further promote the production of active oxygen species for which many components of the cell are targets (Lesser \& Shick 1989). sampled compared with levels 10 mo after the bleaching event (and immediately before the next summer period).

Recently, Le Tissier \& Brown (1996) also measured increases in zooxanthellar chl a concentrations in corals (Goniastrea aspera) during stress-related loss of zooxanthellae following sub-aerial exposure. They suggest the increase in zooxanthellar chlorophyll concentration occurred because of either (1) greater loss of zooxanthellae from the apical tissues (thereby leaving 'dark-adapted' zooxanthellae located in the lower tissues) or (2) breakdown products of chlorophyll and other pigments interfering with the absorption peak used to compute chl a concentrations (Le Tissier \& Brown 1996). Alternatively, the increase may be related to the nutrient status of the algal symbionts. As discussed in Hoegh-Guldberg \& Smith (1989b) and Fitt et al. (1993) the inverse relationship between zooxanthellar density and zooxanthellar chl a concentration (Fig. 6) is the opposite of that expected from a photoadaptive response to zooxanthellar self-shading as zooxanthellar densities increase. The chl a concentration of unicellular algae is also a reliable indicator of nutrient status (Rees 1991), and the relationship may signify nutrient limitation at higher zooxanthellar densities (Hoegh-Guldberg \& Smith 1989b, Fitt et al. 1993, Jones \& Yellowlees

\section{Intraspecific variability in the bleaching response}

Both bleached and unbleached colonies of Acropora formosa lost zooxanthellae during the bleaching event (Fig. 5). Szmant \& Gassman (1990) and Brown et al. (1995) also report that corals can lose significant quantities of zooxanthellae without discolouring. Some of the intraspecific variability in the bleaching response may therefore have been due to the higher level of zooxanthellae loss from the colonies which bleached (65 and $66 \%$ ) as opposed to the normal coloured colonies ( 44 and $48 \%$ ), and the level of zooxanthellae loss required for the colonies to discolour (i.e. $>50 \%$ of the algal standing stock).

Nevertheless, there did appear to be intrinsic differences between the bleached and normal coloured colonies of Acropora formosa sampled over the course of the year. Colony 2, which bleached, had significantly larger zooxanthellae (Fig. 7) after the bleaching event, and naturally lower zooxanthellar densities both before the bleaching event, and at the end of the recovery period (Fig. 5). Ten months after the bleaching event, the other colonies of $A$. formosa known to have bleached also contained inherently fewer zooxanthellae which were larger and had more chl a per cell than the colonies known to have not bleached (Fig. 8). 
There are several lines of evidence to suggest that these represent intrinsic differences between the 2 groups and are not the result of the bleaching event itself. Firstly, the zooxanthellar densities in 2 of the colonies had recovered to a steady-state level $\sim 5$ mo after the bleaching event (Fig. 5) and the colonies were sampled a further 5 mo later. Secondly, the difference in zooxanthellar density between the bleached (Colony 2) and normal-coloured (Colony 4) colonies in December 1994 was evident before the bleaching event occurred. Thirdly, there was no change in the zooxanthellar cell size measured over the course of the year, despite marked changes in zooxanthellar density and chl a concentration, and seasonal changes in water temperature and light İevels.

Significant morphological, biochemical, physiological, behavioural and genetic differences have been documented in zooxanthellae from different hosts (Schoenberg \& Trench 1980a, b, Rowan \& Powers 1991, Banaszak et al. 1993) and within individual hosts (Rowan \& Knowlton 1995). Schoenberg \& Trench (1980b) noted distinct variations in dimensions of recently divided vegetative cells of cultured zooxanthellae isolated from a number of different hosts. Categories of zooxanthellae based on size agreed remarkably well with categories based on isozyme patterns (Schoenberg \& Trench 1980a, b). The zooxanthellae of Acropora formosa at Magnetic Island have not been subject to taxonomic review; however, juvenile colonies acquire zooxanthellae from the external environment, as opposed to from parental inheritance in oocytes. The former process is potentially more prone to the formation of different hostzooxanthellar partnerships. Whether the differences in the size of the zooxanthellar symbionts between the neighbouring colonies of $A$. formosa represent different zooxanthellae taxa is the subject of continuing study.

The results of the present study suggest that loss of zooxanthellae can occur without decreases in zooxanthellar chlorophyll concentrations in Acropora formosa during a warm-water bleaching event. Colonies of $A$. formosa begin to discolour when they have lost $>50 \%$ of their zooxanthellae. Intrinsic differences in the densities, chlorophyll concentrations and zooxanthellar cell sizes between neighbouring colonies may result in intraspecific variability in coral discolouration during a bleaching event.

Acknowledgements. I thank B. Stobart for supplying the seawater temperature data. This work was funded by a GBRMPA augmentative research award and an Australian Coral Reef Society (ACRS) 'Terry Walker' award

\section{LITERATURE CITED}

Asada K, Takahashi M (1987) Production and scavenging of active oxygen in photosynthesis. In: Kyle DJ, Osmond CB. Arntzen CJ (eds) Photoinhibition. Elsevier, Amsterdam, p 228-287

Banaszak AT, Iglesias-Prieto R, Trench RK (1993) Scrippsiella vellelae sp. nov. (Peridinales) and Glenodinium viscum sp. nov. (Phytodiniales): dinoflagellate symbionts of two hydrozoans (Cnidaria). J Phycol 29:517-528

Brown BE, Dunne RP, Scoffin TP, Le Tissier MDA (1994) Solar damage in intertidal corals. Mar Ecol Prog Ser 105: 219-230

Brown BE, Le Tissier MDA, Bythell JC (1995) Mechanisms of bleaching deduced from histological studies of reef corals sampled during a natural bleaching event. Mar Biol 122 : $655-663$

Cook CB, Logan A, Ward J, Luckhurst B, Berg CJ (1990) Elevated temperatures and bleaching on a high-latitude coral reef: the Bermuda event. Coral Reefs 9:45-49

Edmunds PJ (1994) Evidence that reef-wide patterns of coral bleaching may be the result of the distribution of bleaching-susceptible clones. Mar Biol 121:137-142

Fisk DA, Done TJ (1985) Taxonomic and bathymetric patterns of bleaching in corals, Myrmidon reef (Queensland). Proc 5th Int Coral Reef Congress, Tahiti 6:149-154

Fitt WK, Spencer HJ, Halas J, White MW, Porter JW (1993) Recovery of Montastrea annularis in the Florida Keys after the 1987 Caribbean 'bleaching event' Coral Reefs 12: $57-64$

Fitt WK, Warner ME (1995) Bleaching patterns of 4 species of Caribbean reef corals. Biol Bull (Woods Hole) 189:298-307

Ghiold J, Smith SH (1990) Bleaching and recovery of deepwater, reef dwelling invertebrates in the Cayman Islands, B.W.I. Caribb J Sci 26:52-61

Glynn PW (1984) Widespread coral mortality and the 1982-1983 El Niño warming event. Environ Conserv 11: $133-146$

Glynn PW, Imai R, Sakai K, Nakano Y, Yamazato K (1992) Experimental responses of Okinawan (Ryuku Islands, Japan) reef corals to high sea temperature and UV radiation. Proc 7th Int Coral Reef Symp, Guam 1:27-37

Hoegh-Guldberg O. Salvat B (1995) Periodic mass bleaching and elevated seawater temperatures: bleaching of outer reef slope communities in Moorea, French Polynesia. Mar Ecol Prog Ser 121:181-190

Hoegh-Guldberg O, Smith GJ (1989a) The effects of sudden changes in light, temperature and salinity on the population density and export of zooxanthellae from the reef corals Seriatopora hystrix and Stylophora pistillata. J Exp Mar Biol Ecol 129:279-303

Hoegh-Guldberg O. Smith GJ (1989b) Influence of population density of zooxanthellae and supply of ammonium ions on the biomass and metabolic characteristics of the reef corals Seriatopora hystrix and Stylophora pistillata. Mar Ecol Prog Ser 57:173-186

Iglesias-Prieto R, Matta JL, Robins WA, Trench RK (1992) Photosynthetic response to elevated temperature in the symbiotic dinoflagellate Symbiodinium microadriaticum in culture. Proc Natl Acad Sci USA 89:10302-10305

Jaap WC (1988) The 1987 zooxanthellae expulsion event at Florida Reefs. In: Ogden J, Wicklund R (eds) Mass bleaching of coral reefs in the Caribbean: a research strategy. NOAA Undersea Res Prog Res Rep 88-2:24-29

JMP (1994) JMP statistics and graphics guide. SAS Institute Inc, Cary, NC

Johannes RE, Wiebe WJ (1970) Method for determination of 
coral tissue biomass and composition. Limnol Oceanogr 15:822-824

Jones RJ (1997) Zooxanthellae loss as a bioassay for assessing stress in corals. Mar Ecol Prog Ser 149:163-171

Jones RJ, Berkelmans R, Oliver J (1997) The recurrent bleaching of corals at Magnetic Island relative to air and seawater temperature. Mar Ecol Prog Ser 158:289-292

Jones RJ, Steven A (1997) Effects of cyanide on corals in relation to cyanide fishing on reefs. Mar Freshwat Res (in press)

Jones RJ, Yellowlees D (1997) Regulation and control of intracellular algae $(=$ zooxanthellae $)$ in hard corals. Phil Trans $R$ Soc Lond B Biol Sci 352:457-468

Kleppel GS, Dodge RE, Reese CJ (1989) Changes in pigmentation associated with the bleaching of stony corals. Limnol Oceanogr 34:1331-1335

Lesser MP, Shick JM (1989) Effects of irradiance and ultraviolet radiation on photoadaptation in the zooxanthellae of Aiptasıa pallida: primary production, photoinhibition, and enzymatic defenses against oxygen toxicity. Mar Biol 102: $243-255$

Le Tissier MDA, Brown BE (1996) Dynamics of solar bleaching in the intertidal reef coral Goniastrea aspera at Ko Phuket, Thailand. Mar Ecol Prog Ser 136:235-244

Muscatine L, Grossman D, Doino J (1991) Release of symbiotic algae by tropical sea anemones and corals after cold shock. Mar Ecol Prog Ser 77:233-243

Ogden J, Wicklund R (eds) (1988) Mass bleaching of coral reefs in the Caribbean: a research strategy. NOAA Undersea Res Prog Res Rep 88-2

Oliver $J$ (1985) Recurrent seasonal bleaching and mortality of corals on the Great Barrier Reef. Proc 5th Int Coral Reef Congress, Tahiti 4:201-206

Porter JW, Fitt WK, Spero HJ, Rogers CS, White MW (1989)

Editorial responsibility: Anthony Underwood (Contributing Editor), Sydney, Australia
Bleaching in reef corals: physiological and stable isotopic responses. Proc Natl Acad Sci USA 86:9342-9346

Rees TAV (1991) Are symbiotic zooxanthellae nutrient deficient? Proc R Soc Lond Ser B Biol Sci 243:227-233

Rowan R, Knowlton N (1995) Intraspecific diversity and ecological zonation in coral-zooxanthellar symbiosis. Proc Natl Acad Sci USA 92:2850-2853

Rowan R, Powers DA (1991) Molecular genetic identification of symbiotic dinoflagellates (zooxanthellae). Mar Ecol Prog Ser 71:65-73

Schoenberg DA, Trench RK (1980a) Genetic variations in Symbiodinium (=Gymnodinium) microadriaticum Freudenthal, and specificity in its symbiosis with marine invertebrates. I. Isoenzyme and soluble protein patterns of axenic cultures of Symbiodinium microadriaticum. Proc $\mathrm{R}$ Soc Lond Ser B Biol Sci 207:405-427

Schoenberg DA, Trench RK (1980b) Genetic variations in Symbiodinium (=Gymnodinium) microadriaticum Freudenthal, and specificity in its symbiosis with marine invertebrates. II Morphological variation in Symbiodinium microadriaticum. Proc R Soc Lond Ser B Biol Sci 207:429-444

Stobart B (1994) Delimiting coral species using alternative techniques: Montipora digitata (Dana, 1846), a case study. PhD thesis, James Cook University, Townsville

Szmant AM, Gassman NJ (1990) The effects of prolonged 'bleaching' on the tissue biomass and reproduction of the reef coral Montastrea annularis. Coral Reefs 8:217-224

Yamazato K (1981) A note on the expulsion of zooxanthellae during summer, 1980 by the Okinawan reef-building corals. Sesoko Mar Sci Lab Tech Rep 8:9-18

Yonge CM, Nicholls AG (1931) Studies on the physiology of corals. IV. The structure, distribution, and physiology of the zooxanthellae. Sci Rep Great Barrier Reef Exped 1928-1929:135-176

Submitted: December 1, 1996; Accepted: July 22, 1997

Proofs received from author(s): October 21, 1997 